weather forecasting is an accurate prediction of changes in the field of atmospheric pressure in the upper air as well as in the strength and movements of the familiar depressions and anticyclones at groundlevel. It is interesting to see that trials of methods of numerical calculation of these changes were begun in the Forecast Research Division. On the physical and instrumental sides, the work in progress included research into the visibility of the ground from aircraft flying in fog or haze and, with the aid of radar and direct observation from aircraft of the Meteorological Research Flight, into the formation of rain and other aspects of cloud physics. The director of the Office, Sir Nelson Johnson, presided over the final conference of directors of the International Meteorological Organization, which opened in Paris on March 15, 1951, in his capacity as president of the Organization. He was elected president of the World Meteorological Organization, the first Congress of which was held in Paris last March.

\section{Linen Industry Research Association: Report for} 1951

THE report of the council of the Linen Industry Research Association for the year ended September 30, 1951 (pp. 20; from the Association, Lambeg, Co. Antrim; 1951), records a membership of 289, compared with 281 at the end of the previous year, but the Association failed by a small margin to reach the trade subscription of $£ 32,000$ required to earn the maximum government grants. These have been fixed for the next quinquennium just short of the maximum of $£ 22,000$ and $£ 13,000$ from the Department of Scientific and Industrial Research and the Government of Northern Ireland, respectively. Much of the time of the staff continues to be occupied in the solution of day-to-day problems, and surveys of factories still form an important part of weaving research. Work on loom motions has borne fruit in a new design of universal shedding motion and a special form of picking shoe. Scutching trials have shown that the Van Hauwaert automatic spreader can be used with a turbine scutching machine fitted with the modified roller breaker, and further trials have confirmed that the design of the Linra modified roller breaker is satisfactory and that the equipment is ready for factory trials. A new precision type of stub remover has been designed and patented for improving the quality of yarns by removing the gross faults, such as spinner's piecings and flyovers, during high-speed winding, and the equipment is now being developed for commercial application. Work is also being carried out to improve the sizing of spun rayon yarns by adding to the tape-sizing machine an apparatus for wet-splitting and brushing the yarn, as well as to improve the production of level and well-penetrated dyeings on linen and rayon fabrics; in addition, promising results have been obtained in work on rot-proofing linen goods.

Parliamentary and Scientific Committee: Report for 1951

THE annual report for 1951 of the Parliamentary and Scientific Committee (pp. 20; from the Committee, 31 Palace Street, London, S.W.1; 1952) contains the customary particulars of officers, subscribing membership and reports of the annual general meeting and annual luncheon on January 30, 1951, with a list of addresses and discussions arranged during the year. The discussions have included the progress and development of atomic energy in Cireat
Britain, the work and future plans of the National Research Development Corporation, the future development of higher technological education, the contribution of science and technology to overcoming shortages of essential raw materials, the assistance given by the Economic Co-operation Assistance Mission to the United Kingdom in the scientific and technological field, the organization, work and plans of the Meteorological Office, and agricultural research, with special reference to cows and insects. Following a discussion in May on the application of science and technology, a sub-committee was set-up to review this question and to advise what more could usefully be done to ensure the better application of science and technology in the British Colonies. Although no further reports have been issued during the past year on scientific man-power or fuel efficiency, both subjects have received attention from the Committee, and questions on various aspects of them have been asked or debated in Parliament during the year.

\section{Recent Work of the Social Survey}

A LIST of subjects investigated by the Social Survey Division of the Central Office of Information, during the past two years 1950-52, which was supplied by the Financial Secretary to the Treasury in reply to a question in the House of Commons on March 11 and printed in Hansard for that date, includes three investigations commissioned by the Department of Scientific and Industrial Research. One, on sound in dwellings, is an investigation, under actual daily living conditions, of the extent to which a new type of party wall reduced the amount of noise heard in local-authority dwellings. The second is a pilot study of the present distribution of science graduates made with the view of showing whether the Scientific Civil Service is recruiting its necessary share of the better graduates, and obtaining the reasons for not entering the Civil Service. The third is a pilot study to measure the flow of scientific information to industry, with the view of improving the work of the Technical Information Service of the Department. Also of some scientific interest are the investigations made for the Ministry of Labour into the employment of elderly workers, for the Ministry of Health on the nutritional level of children under the age of five years and on new problems in diphtheria immunization, and the statistical studies for the RegistrarGeneral's Office designed to show the incidence of ill-health and injuries as well as the use made of the national medical service.

\section{Professional Engineers Appointments Bureau : Activities during 1951}

The Professional Engineers Appointments Bureau, 9 Victoria Street, Westminster, London, S.W.1, an organization which exists mainly for the placing of members of the Institutions of Civil, Mechanical and Electrical Engineers in suitable positions of employment, has recently reviewed its activities during 1951 . The total of vacancies notified by employers was 1,070, of which 314 were for civil, 503 for mechanical and 253 for electrical engineers; overseas vacancies were approximately 30 per cent of these figures, and were in the main for the Middle East, West and East Africa, India and Pakistan. The Bureau made 7,276 nominations, of which 2,050 were civil, 3,444 mechanical and 1,782 electrical. Compared with 1,947 in 1950 and 1,981 in 1949, enrolments at the end of the year totalled 1,679, of which 385 were civil, 766 mechanical and 528 electrical engineers. This decrease 